\title{
Work-Life Balance: A Study of Selected Nationalized Banks in Ambala District (Haryana)
}

\author{
Ms. Pooja Maken"1, Dr. Kavita Aggarwal² \\ ${ }^{*}$ Department of Management, M.M. University, Mullana, Ambala, Haryana, India \\ ${ }^{2}$ Department of Management , Rayat Bahra University, Mohali, Punjab, India
}

\begin{abstract}
Article Info

Volume 8, Issue 2

Page Number : 203-213

\section{Publication Issue}

March-April-2021

\section{Article History}

Work-life and personal life are two sides of the same coin. Increasing work burdens, globalization and industrial development have made it an issue with both the sexes, all professionals, working across all levels and all businesses throughout the world. The banking industry is one that is fronting the force of the threat of work-life imbalance. Due to this work burden, it becomes exceedingly difficult to maintain work-family life. Many a time, people, in the quest for reaching the top, work so hard, that they miss out on the real pleasures of life. While it is absolutely great to have a flourishing career, it is equally domineering to have a life external work. Work-life balance can be defined as the perfect integration between work and life both not interfering with each other. There are a number of variables that affect positive and negative impact on Work-life balance. So the present study examines the "Work-life balance - A study of selected nationalized banks in Ambala District (Haryana). The study revealed that most employees satisfied with Work-life balance policy offered by banks.
\end{abstract}

Accepted : 01 March 2021

Published : 04 March 2021
Keywords : Work-Life Balance, Work Pressures, Occupational Stress, Employees of Banks, Ambala.

\section{INTRODUCTION}

Work-life and personal life are interconnected and interdependent. Spending more time in office, allocating with customers and the burdens of the job can delay and affect personal life, sometimes making it difficult to even complete the domestic responsibilities. On the other hand, personal life can also be demanding if you have a kid or ageing parents, financial problems or even problems in the life of a dear relative. It can lead to skiving from work, creating pressure and lack of awareness at work. Work-personal life conflict occurs when the burden, commitments and responsibilities of work and family roles become mismatched. The obligation of one can force an individual to neglect the other. 
There is no 'one size fits all' pattern of work-life balance practices. It is important for employers to offer practices that appeal to all employees. Employers may incur extra costs in assuming strategies to support work-life balance, including enlarged managerial capabilities.

\subsection{Factors Influencing Work-Life Balance}

In the globally competitive world, the term WorkLife Balance is gaining importance and its time for companies to start thinking strategically and come up with innovative solutions which provide a better balance between work and life for its employees.

Works-Overloaded- There are many dimensions to work demands, such as time pressure-tight deadline, high speed of work, and the quantity of work (workload). Work overload is likely to have a dual effect on work-life conflict. The high workload is likely to increase work hours and also to contribute to feelings of strain and exhaustion.

Training Programmers-Training programmers for employees help to built skills, and to encourage employees to use technology more efficiently. This will build confidence in the employees which will help in increasing the performance and the productivity of the organizations and useful training programs should be provided to have better work-life balance.

Working environment-While determining the worklife balance of an employee the presence of a comfortable environment inside the organization encourages the employee and motivates them to complete the task assigned in the specific time. The ability to complete the job in time itself is a strong factor to achieve work-life balance.

Work-life programmers-The indent of various worklife programmers aims to free the employees from the hectic work schedule so that he or she can spend more time with the family.
Relocation-When an employee climbs up the ladder of the career in the job leads to the dislocation of the family which badly affects their work-life balance.

Working hours- Excessively long working hours force employees to escape many of their family responsibilities, which imbalances their work and family lives. Since these negative emotional regulation decreases job satisfaction and increases turnover, employers are now becoming more conscious about implementing such policies as streamlining the work and family of their employees.

Fringe Benefits- Fringe benefits are those which are being paid to employees in addition to their salary. It includes paid holidays, subsidized food, maternity and paternity leave, health insurance, educational facilities for children, etc.

Childcare- Women, especially Indian women, pay more attention to the family than their career. The need to take care of the children while away from home is a vital factor which disturbs their mind and diverts their attention from their office work.

Family Support system- the support from the employee family contributes to the work-life balance. The need to take care of the children while away from home is a vital factor which disturbs their mind and diverts their attention from their office work.

\subsection{Indian Banking Sector}

Banking Sector in India has undergone a transformation after liberalization in 1990 by Narsimha Rao government where they issued a license to a small number of private banks. Banks have also diversified their activities in new products and services as per the requirement of the business. Due to the dynamic nature of the financial markets and the rapid changes in the economic reforms, a need for efficient products and services in the banking sector had become important for its survival and existence. 
An increase in educated customers and the emerging competition had generated high expectations from such a banking industry. The new rules of the competition and the advancement in technology have revolutionized the Indian financial and banking sector. These changes demand more effective employees to help the banks achieving its objectives.

\section{Review of Literature}

Sindhuja, K., and S. Sekar Subramanian (2020) examined the effectiveness of the work-life Balance of bank employees and its impact on employee retention in the selected banks in Sivakasi, Virudhunagar district. The findings of the study reveal that 44 percent of the respondents have a low level of worklife balance, 40 percent of the respondents have a medium level of work-life balance, and only 16 percent of the respondents perceived a high level of work-life balance. The study also identified that there is a significant difference between the work-life balance levels among the public sector and private bank employees.

Ms. Simarpreet kaur, Dr. Kavita Aggarwal (2019) examined that what types Work life balance policy offered by nationalized banks in Mohali District. One independent (occupational stress) and one dependent variable (WLB) was taken to know the exact condition of Work life balance policy followed by the banks. Through the study it was analyzed was the employees were gratified with the WLB policy offered by the selected banks. It was found that that Occupational stress had a negative relation to the employees work-life balance in the selected banks in Mohali District.

Dr. Sumati Ray, Dr. K.C. Paul (2019) examined and compared the stress on work in public and private sector bank employees in India. This paper is having Indian experience with reference to West Bengal
State on comparison of stress between Public and private bank employees. The study concludes that the both sector bank employees were overburden with the work load in their workplaces and banking sector is not playing an active role in Stress Management programs for the employees in both private sector as well as public sector banks. The stress is more in private banks compare to public sector banks as both the banks employees are bound to give business to the bank but the pressure is more in private sector banks than public sector banks subject to the job security.

Kshirsagar R. Sonali (2018) examined on Women Employee Work-Life Balance of service sector namely Academics, Banks and Health care sector of Aurangabad Region. An attempt was done to study the existence of Work-Life Balance problem among the working women in the specified area. It was tried to examine how the factor affecting work-life balance influence quality of life of married working women. The study revealed that $83.33 \%$ of the Women employees were found saying that the Work Life provided to them was worst, they may be under substantial stress due to lack of work-life balance. 10\% of the employee were in moderate state depicts that they are not entirely in happy work-life balance, but in a good position not to let the situation get out of control and $6.6 \%$ were in Best state that they have a balanced work-life and able to effectively manage their families.

\section{Objectives}

- To study the work-life balance of selected nationalized banks in Ambala District.

- To study the Occupational stress of selected nationalized banks in Ambala District.

- To investigate the relationship between occupational stress with employees Work-life Balance in selected banks of Ambala District 
- To study the HR policies and practices being adopted by the selected Nationalized banks to promoting healthy work-life balances

\section{IV.Scope of Study}

The study will be conducted at all the three levels i.e. top, middle and lower levels of the employees will be present the comprehensive picture of Work-life Balance in the respected selected banks.

The following banks will be selected- :

\section{Nationalized Banks}

- Punjab National Bank

- State Bank of India

\section{Research Methodology}

In the present study, both Primary and Secondary data is considered. Primary data is collected through questionnaire and distributed to the 60 employees of selected nationalized banks in the Ambala District using five-point Likert Scale. In addition to this, the secondary data was collected from various newspapers, magazines, books, websites, and research journals etc.

\subsection{Research Design}

The research design of the present study comprises of one independent variable (Occupational stress) and one dependent variable (Work-life Balance). Besides its demographic variables such as Age, Education, Gender and Marital status were taken to check the relationship between Work-life Balance and Occupational stress.

\subsection{Independent Variable}

\section{Occupational Stress}

Occupational or workplace stress can be defined as the change in one's physical or mental state in response to a workplace that poses an appraised challenge or threat to that employee. Causes of occupational stress include environments, organizational climate, and a conflict arises from the job demands of the employees. Psychologic disorders may lead to poor work performance, higher absenteeism, less work productivity even injury. Stressful working conditions can lead to behavioural, physical, and psychological strains.

\subsection{Dependent Variable}

\section{Work-life Balance}

Work-life balance is about creating and maintaining supportive and healthy work environments, which will enable employees to have a balance between work and personal responsibilities and thus strengthen employee loyalty and productivity. It helps us in addressing all those areas of our life that should co-exist peacefully, in spite of belonging to different spheres.

\section{Data Analysis and Discussion}

Table-1. Demographic characteristic (based on questionnaire in the area of Ambala District)

\begin{tabular}{|l|l|l|l|}
\hline Variables & Categories & No of Respondents & Percentage \\
\hline Gender & Male & $32+4=36$ & 60 \\
& Female & $18+6=24$ & 40 \\
\hline Age & $20-25$ & $4-1=3$ & 5 \\
& $26-30$ & $9+3=12$ & 20 \\
& $31-35$ & $18+3=21$ & 35 \\
& $36-40$ & $11+4=15$ & 25 \\
& Above 40 & $8+1=9$ & 15 \\
\hline
\end{tabular}




\begin{tabular}{|l|l|l|l|}
\hline Education & Matric & 0 & 0 \\
& Higher Secondary & $5+1=6$ & 10 \\
& Graduate & $21+3=24$ & 40 \\
& Post Graduate & $20+1=21$ & 35 \\
& Others & $4+5=9$ & 15 \\
\hline Marital status & Married & $31+2=33$ & 55 \\
& Unmarried & $19+8=27$ & 45 \\
\hline
\end{tabular}

On the basis of Gender: Among the respondents, $60 \%$ are male whereas $40 \%$ are female.

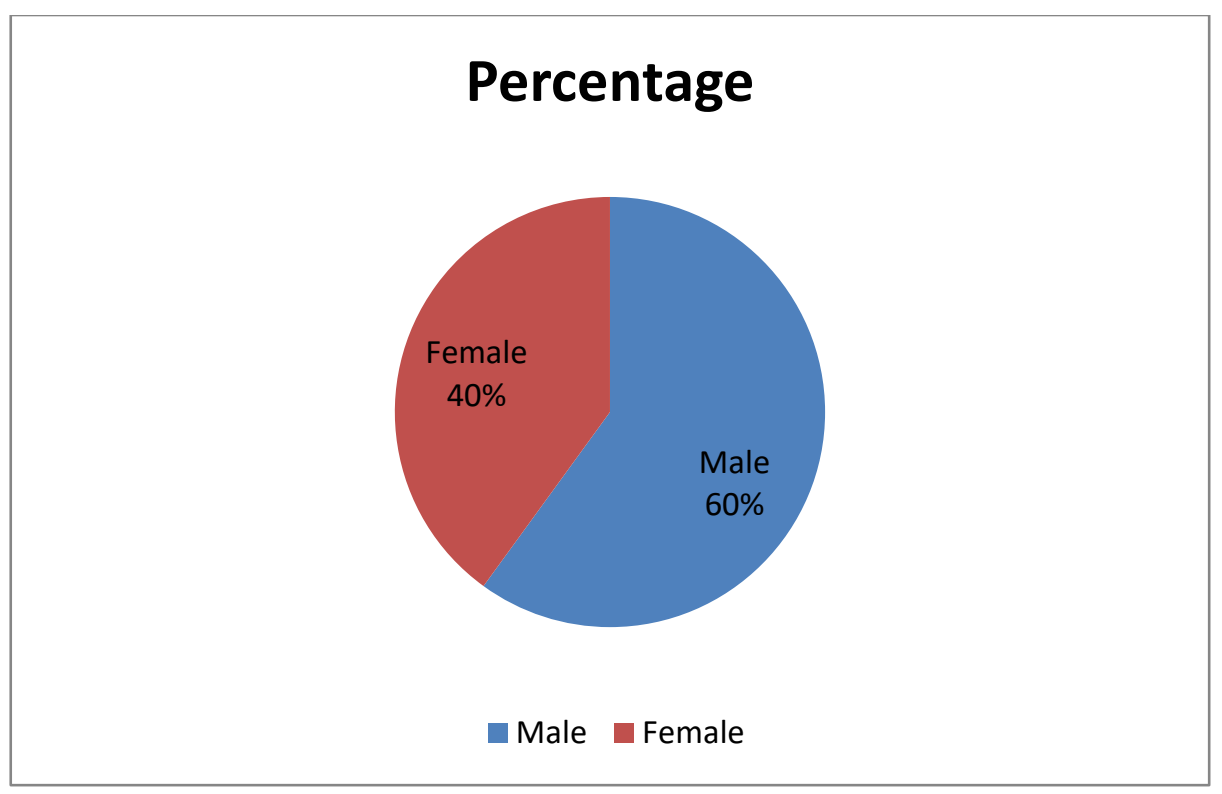

On the basis of the Age the respondents: Among the respondents $35 \%$ belong to the age category of $31-35$ years followed by $25 \%$ in $36-40$ years, $20 \%$ in age group of $26-30$ years, $15 \%$ age group belong to the above 40 years and $5 \%$ belong to $20-25$ age group.

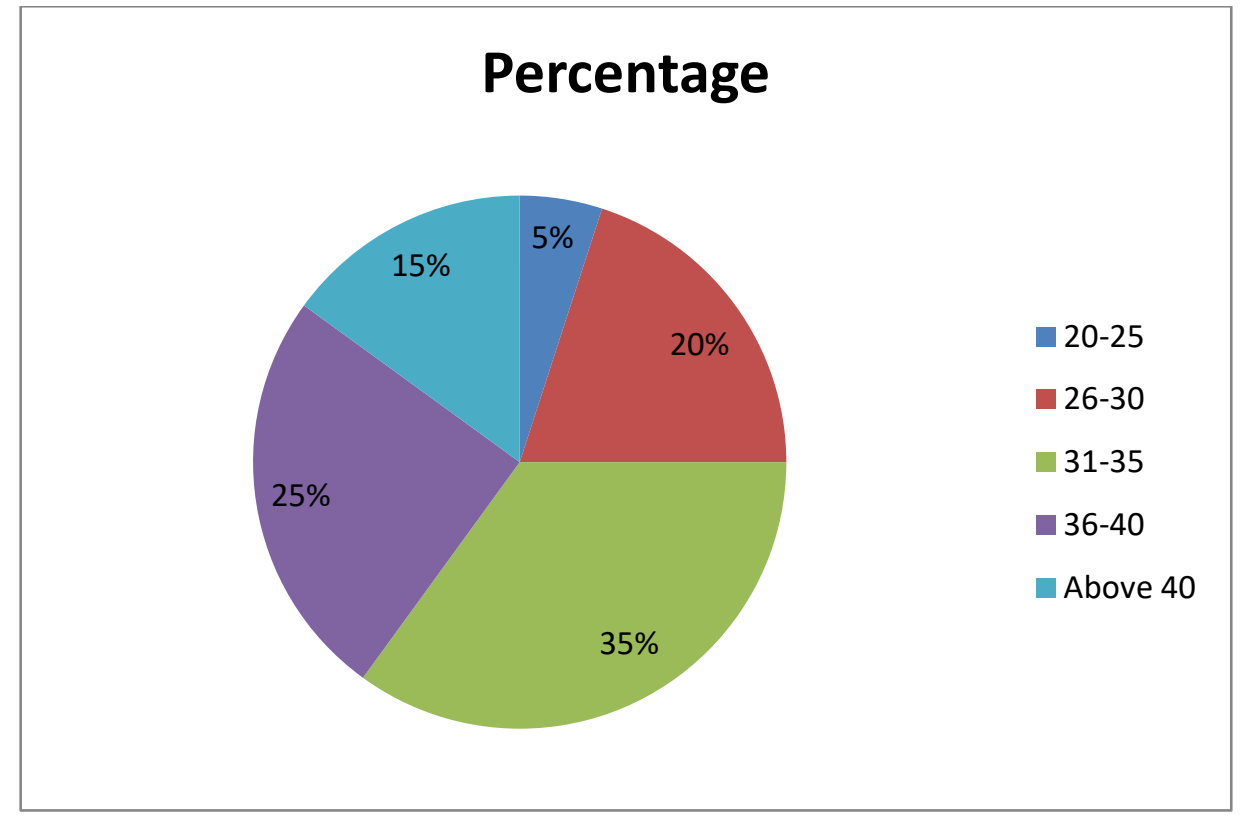


On the basis of Educational qualification of the respondents: $40 \& 35 \%$ are graduates and postgraduates and $10 \& 15 \%$ are higher secondary and others. There is no respondents belong the matric qualification.

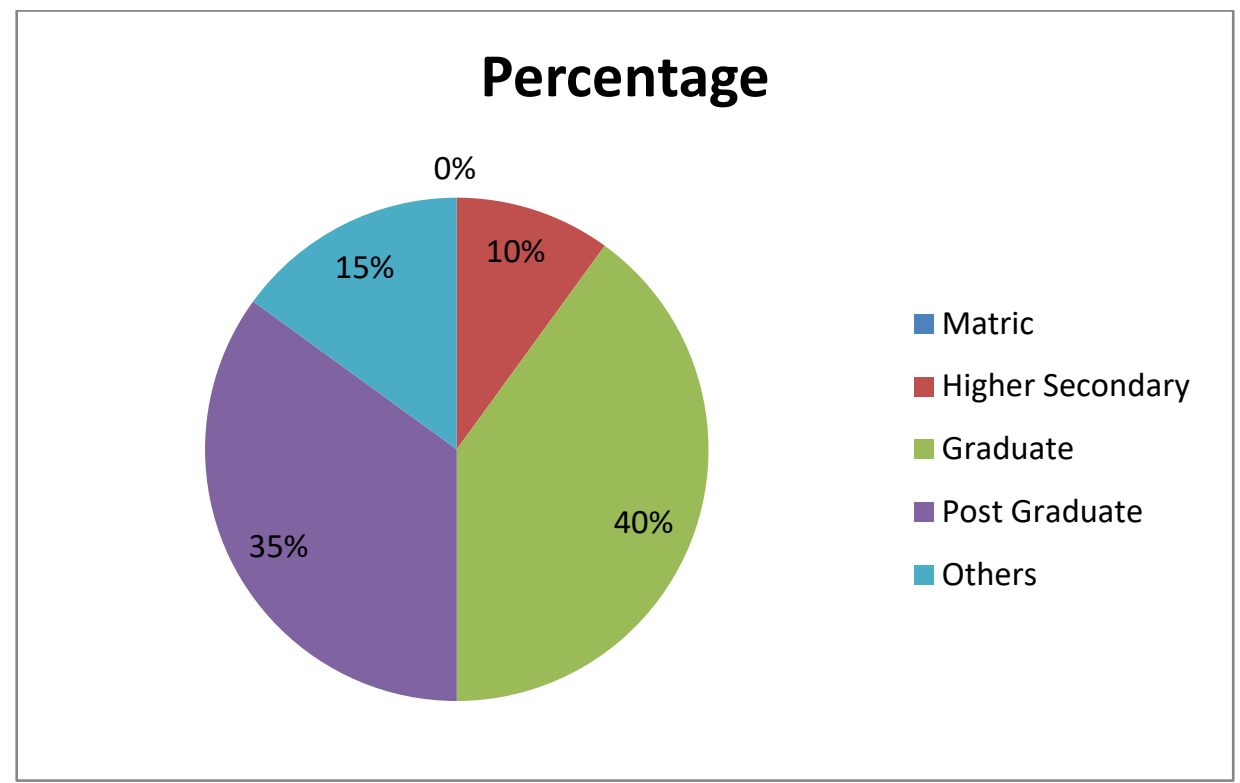

On the basis of Marital Status: Among the respondent is $55 \%$ were married and $45 \%$ are unmarried.

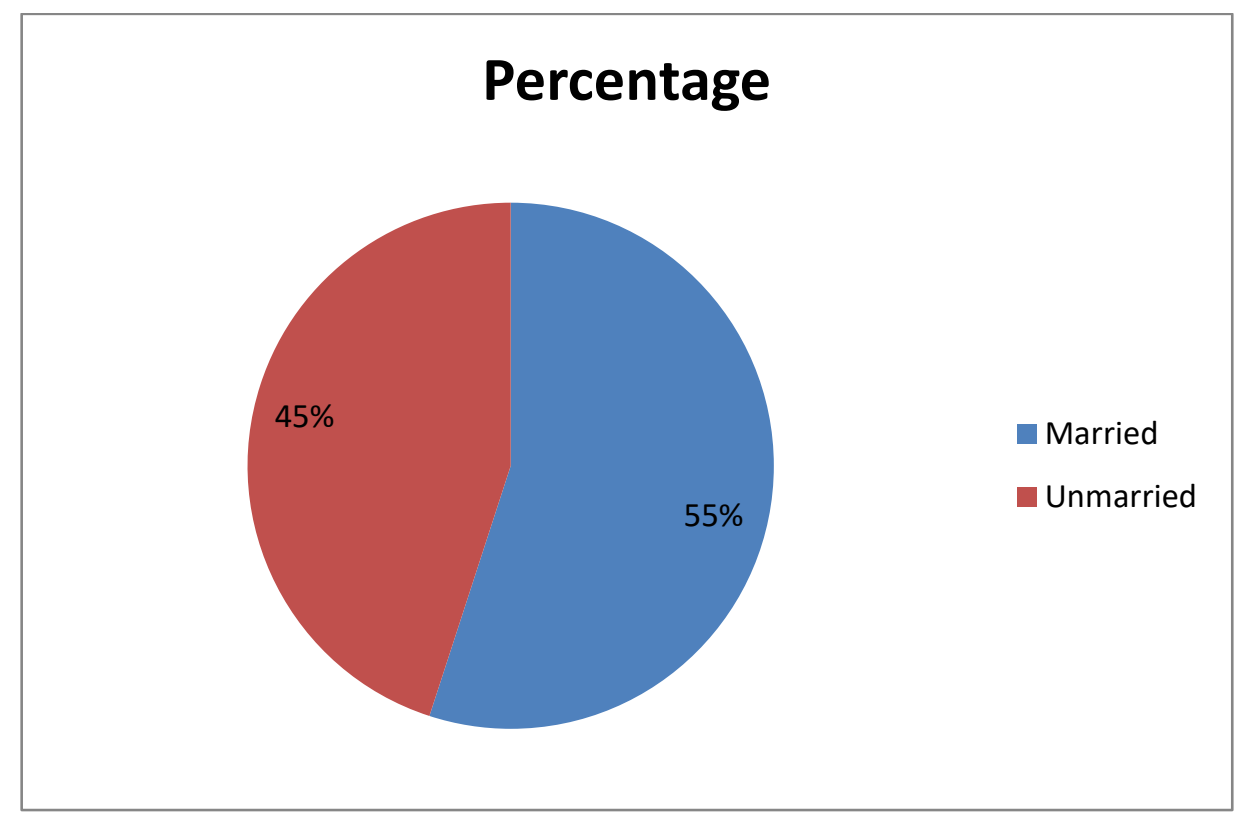

Responses of Bank employees regarding the Work-life balance in the nationalized bank situated in Ambala District.

\begin{tabular}{|l|l|}
\hline $\mathbf{1}$ & I leave work/office on time on most of the days \\
\hline $\mathbf{2}$ & Employers take long working hours for granted \\
\hline $\mathbf{3}$ & I often take my office work at home \\
\hline $\mathbf{4}$ & Management can be trusted to do things that employee want to do in their own way \\
\hline
\end{tabular}




\begin{tabular}{|l|l|}
\hline $\mathbf{5}$ & My performance targets set by management are reasonable \\
\hline $\mathbf{6}$ & I can devote sufficient time for household responsibilities \\
\hline $\mathbf{7}$ & Employees are treated with equal fairness \\
\hline $\mathbf{8}$ & I am satisfied with the balance between my work and personal life \\
\hline
\end{tabular}

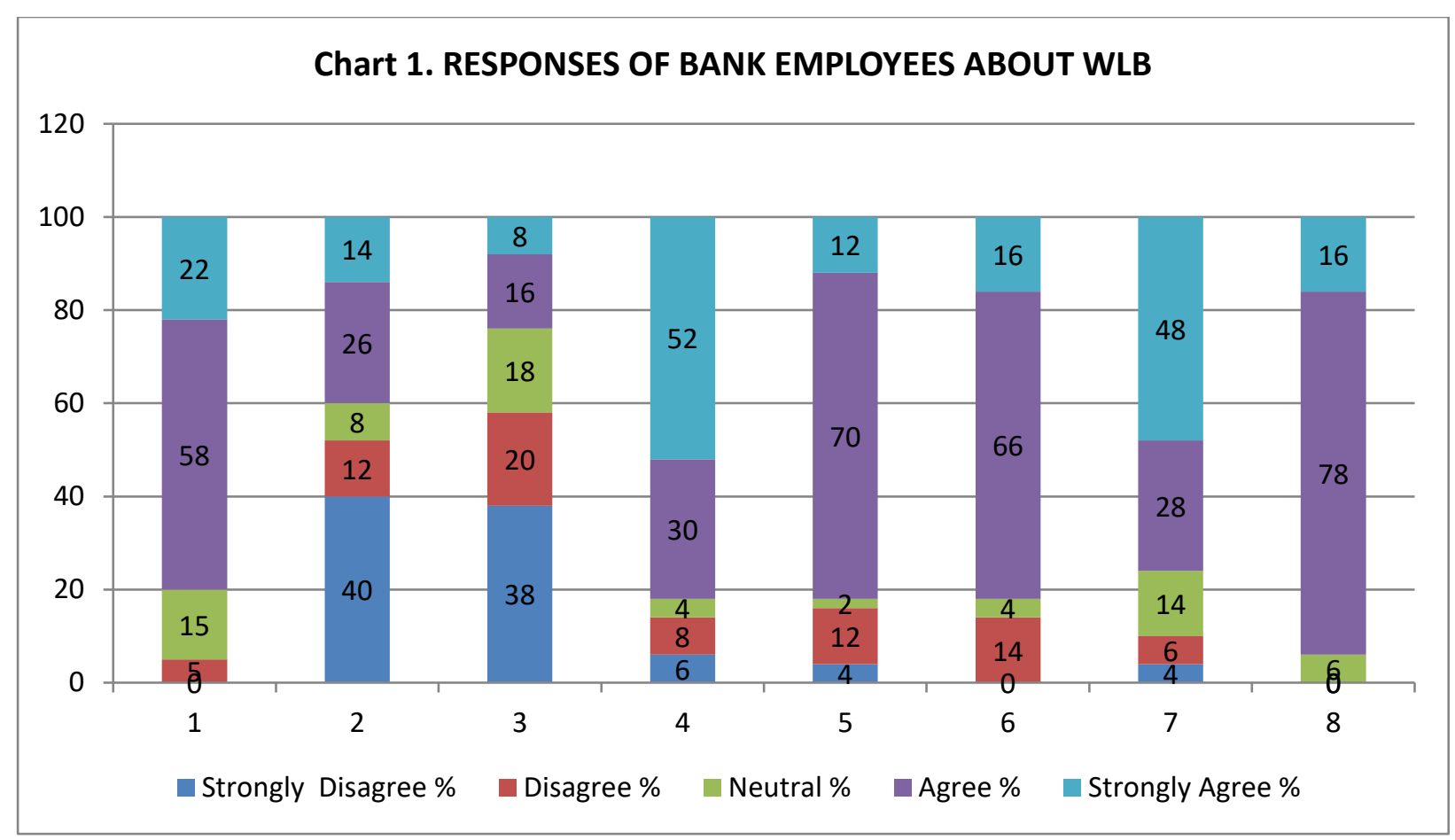

It can be seen from the table- 2 that most of the respondents were satisfied by the policy of worklife balances offered by the nationalized banks in Ambala. They offered policy like -leave the office at the time, management trusted employees and equal fairness to all employees and they can give proper time to household responsibility. In bar graph responses of eight questions has been mentioned in Percentage.

Table -3. Responses of Bank employees regarding the Occupational Stress in the nationalized bank situated in Ambala District.

\begin{tabular}{|l|l|}
\hline $\mathbf{1}$ & I am paid a low salary as compared to my labour and work \\
\hline $\mathbf{2}$ & $\begin{array}{l}\text { I find it difficult to establish an equilibrium between political/group pressures and formal } \\
\text { rules and instructions. }\end{array}$ \\
\hline $\mathbf{3}$ & $\begin{array}{l}\text { When new work is assigned to me, neither clear instructions are given nor are adequate } \\
\text { means provided. }\end{array}$ \\
\hline $\mathbf{4}$ & Some of the work is risky and complicated. \\
\hline $\mathbf{5}$ & The limits of my work and powers are uncertain and ambiguous. \\
\hline $\mathbf{6}$ & Some of my colleagues and subordinates try to defame me. \\
\hline $\mathbf{7}$ & I have experienced that because of the job my life has become a burden. \\
\hline $\mathbf{8}$ & I have to do some work unwillingly due to mass political pressure. \\
\hline
\end{tabular}




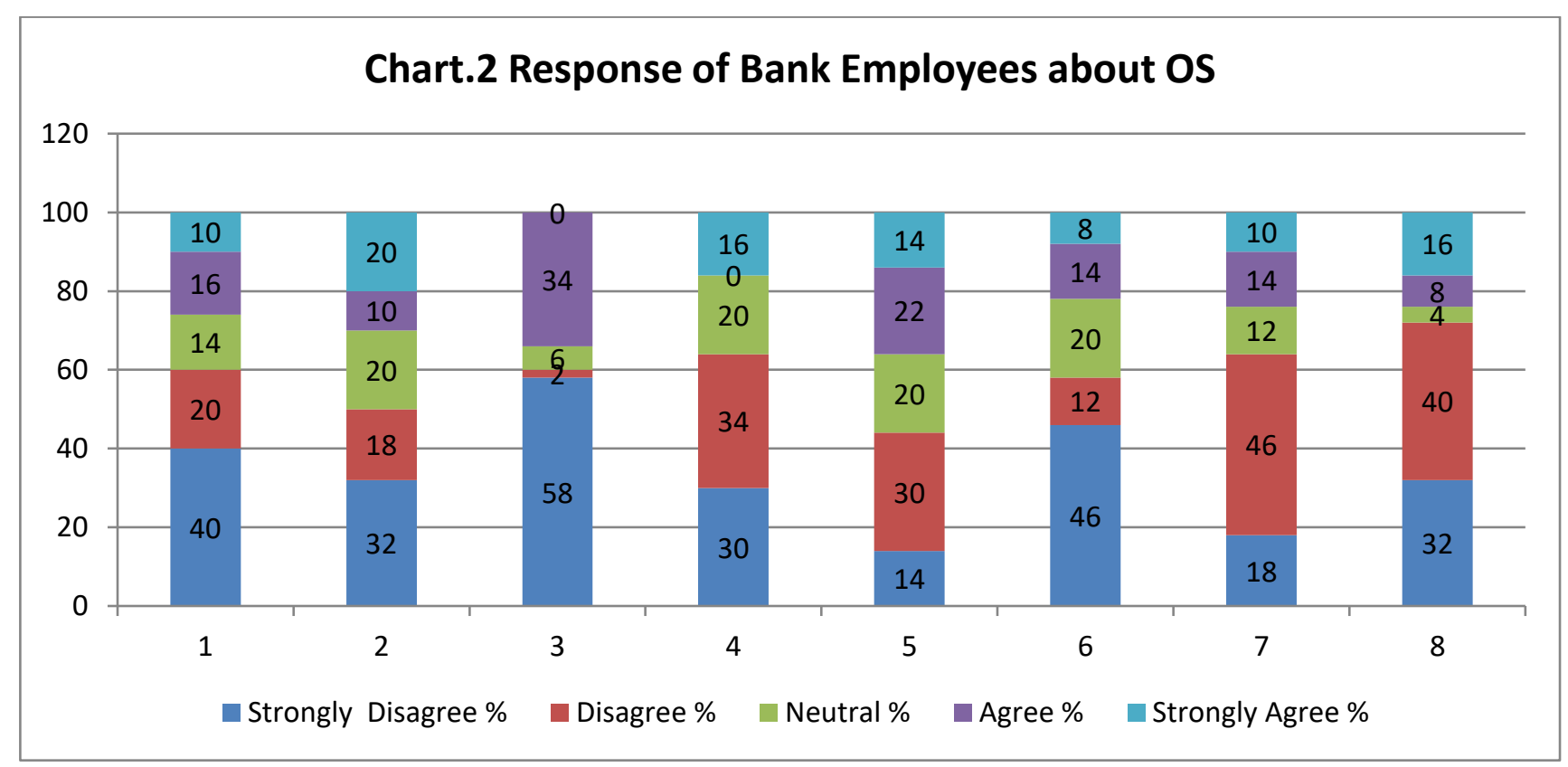

According to the table-3, it can be concluded that Occupational stress had a negative related to the employee's work-life balance in the selected banks in Ambala District. Most of the employees disagree to have occupational stress in their organization. In bar graph responses of eight questions has been mentioned in Percentage.

The Relationship between Work-life Balance and Occupational stress among Nationalized banks.

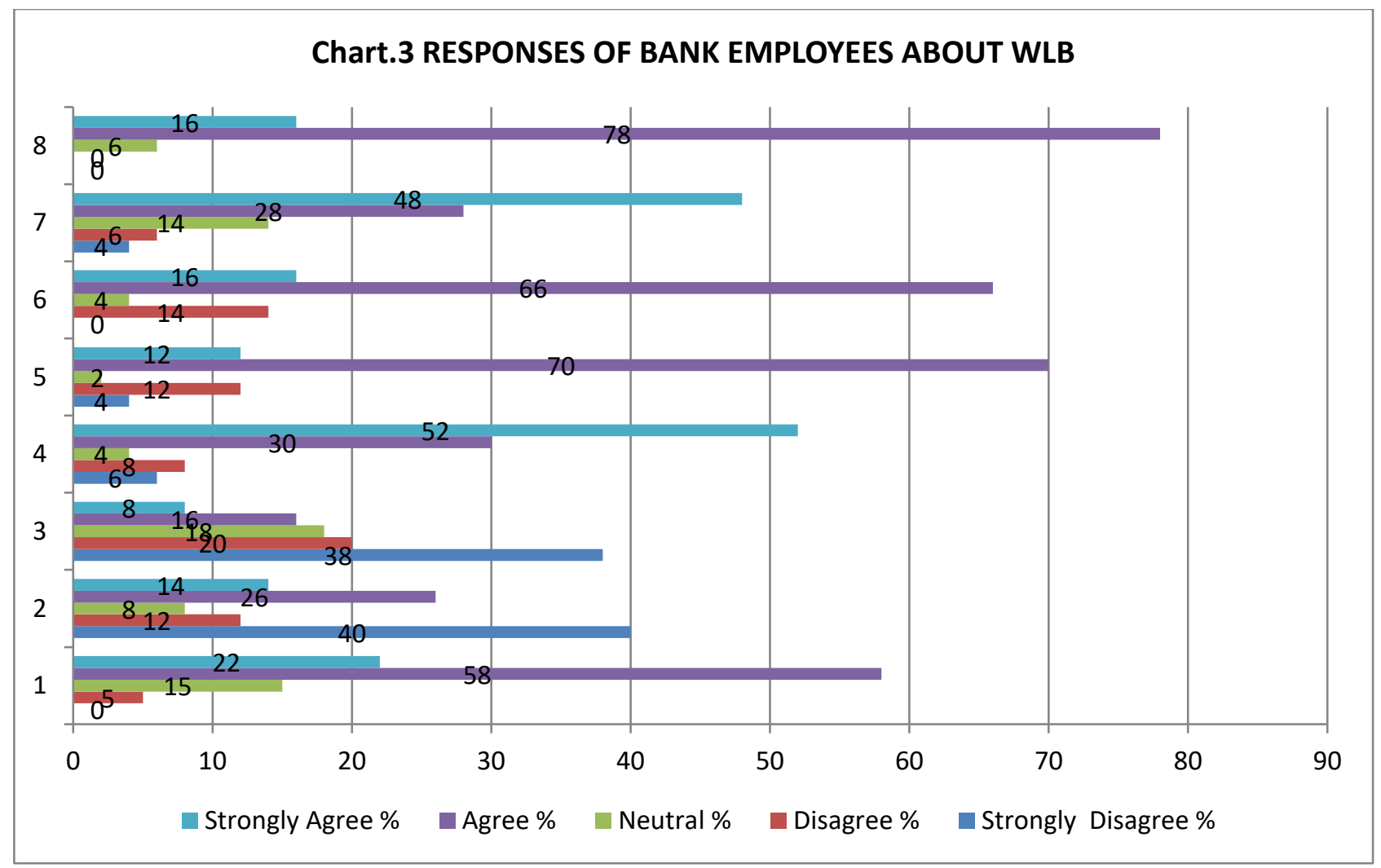




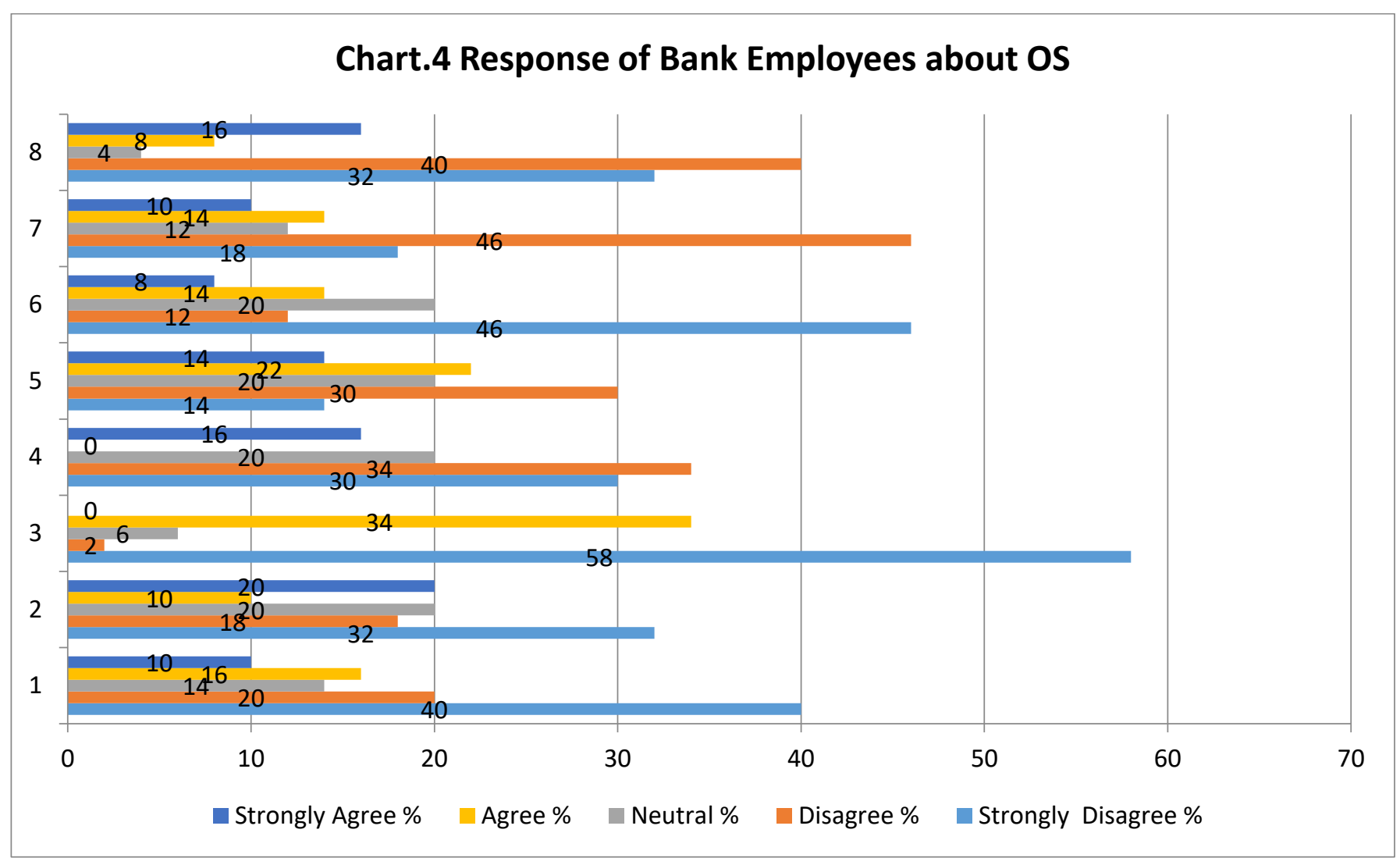

In chart-1 represent the Work-life balance and Chart2 depict the Occupational stress in the nationalized banks in Ambala. The Occupational stress was the independent variable and Work-life balance was dependent. It was cleared showed that Work-life balance depends on the Occupational stress. In this study, it was found that Occupational stress had a negative relation to the employee's work-life balance in the selected banks in Ambala District. Through the study, it was analyzed that the employees are satisfied with Work-life balance policy offered by the selected banks. Since nationalization banking sector is considered to be one of the major employees, even people prefer banks as a career as the social status and wages are good enough. Indian worker feelings are very emotions and any legal contract will not motivate them. Instead there should be psychological or emotional bond between employees and the organization.

HR policies and practices being adopted by the selected nationalized banks to promoting healthy work-life balance were providing flexible leave arrangements to suit employee's personal needs and Safety and healthy environment were provided to the employees. The non-financial reward was agreed to the employees.

\section{VII.CONCLUSION}

The goal of this study was to augment the knowledge of work-life balance existing in the selected banks of Ambala. A satisfied and happy and hardworking employee is the biggest asset of any organization, including banking sector also. The study focused on what types Work-life balance policy offered by nationalized banks in Ambala District. One independent (Occupational stress) and one dependent variable (WLB) was taken to know the exact condition of Work-life balance policy followed by the banks. Through the study it was analyzed that the employees were gratified with the WLB policy offered by the selected banks. They are satisfied with 
working hours, salary, and cooperation of employer, healthy work environment. It was found that Occupational stress had a negative relation to the employee's work-life balance in the selected banks in Ambala District.

Limitation faced during research process were many bank branches were visited after their normal working hours because during the working hours, it was difficult to get complete information due to public dealing and some respondents showed the little interest in filling the questions.

\section{REFERENCES}

[1]. Asgari. Hadi. Mohammad and Dadashi. Ali. Mohammad, "Determining the relational between Quality of work-life (QWL) and organizational commitment of Melli bank staff in the west domain of Mazandaran," Australian Journal of Basic and Applied Sciences, vol.5, no.2, pp.682-687, August 2011.

[2]. Asma. Zaheer, Jamid.Ul. Islam and Nahid. Darakhsham, "Occupational stress and worklife balance: A study of female faculty of a central university in Delhi” Journal of Human Resources Management, vol.4, no.8, pp.1-5, June 2017.

[3]. Jain Priyesh, Batra Akil, "Occupational stress at workplace study of the Corporate Sector in India, ” Journal of Business and Management, vol. 17, no.11, pp.13-21, June 2015.

[4]. Hangarki.B. Shobha, "Quality of work life among employees in the banking sector. A study was undertaken at Nationalized Banks, Hyderabad Karnataka Region Research," Journal of Humanities and Social sciences, vol. 2, pp.194-197, March 2014.

[5]. Hasnain. N, Ansari. S.A and Ali.S, "Workfamily conflict and occupational stress as correlates of life satisfaction among male and female managers," International Review of Business and Social Science, vol.1, pp.70-79, June 2012.

[6]. Dr Orogbu. Lilian. Obiageli, Dr Onyezugbe.Chinedu. Uzockukwe and Chukwuemeke. Debarah. Ngou, "Work-life balance and employee performance in selected commercial banks in Logos state," European Journal of Research and Reflection in Management Science, vol.3, no.4, pp.112-120, March 2015.

[7]. D.S.R. Adikaram, "Impact of work-life balance on employee job satisfaction in private sector in commercial banks of Sri Lanka," International Journal of Scientific Research and Innovation Technology, vol. 3, no.11, April 2016.

[8]. G.Delina and Dr. R. Prabhakara. Raya, "A study on work-life Balance in working women," International Journal of Commerce Business and Management, vol -2, no-5, September 2016.

[9]. Obulesu Varikunta and M. Sudheer Kumar, "The Level of Employees Job Satisfaction in Public Sector Bank, With Special Reference to SBI Banks in Rayalaseema Division," International Journal of Recent Technology and Engineering (IJRTE), Volume-8 Issue-2, July 2019

[10]. Murtaza Mustafa, EM.Illzam, RK.Muniandy, MI.Hashmi , AM.Sharifa, MK.Nang, "Causes and Prevention of Occupational Stress" IOSR Journal of Dental and Medical Sciences (IOSRJDMS) Volume 14, Issue 11, Nov. 2015

[11]. D. Babin Dhas, "A Report on the Importance of Work-Life Balance" International Journal of Applied Engineering Research, Volume 10, Number 9, 2015

[12]. SARIKA. G \& B. ANITHA, "Work Life Balance of Bank Employees (A Comparative Study at State Bank of India and Karnataka Bank in Andhra Pradesh State)" International Journal of 
Political Science, Law and International Relations (IJPSLIR), Vol. 5, Issue 2, Apr 2015

[13]. Sindhuja, K., and S. Sekar Subramanian. "Impact of Work-Life Balance on Employee Retention- A Study on Banking Sector." Shanlax International Journal of Management, vol. 7, no. 3, 2020, pp. 78-81.

[14]. K. Simarpreet, Aggarwal Kavita (2019). WorkLife Balance: A Study of Selected Nationalized Banks in Mohali District (Punjab). International Journal of Research Culture Society ISSN: 24566683 Volume - 3, Issue - 12, Dec - 2019

[15]. Sudip Basu, Dr. Sumati Ray, Dr. K.C. Paul (2019), "A Study on Stress in Public and Private Sector Bank Employees in West Bengal”, International Journal of Research and Scientific Innovation (IJRSI) | Volume VI, Issue XII, December 2019 | ISSN 2321-2705

[16]. Kshirsagar R. Sonali (2018), "Work-Life Balance of Women Employees in Service Sector", International Journals of Advanced Research in Computer Science and Software Engineering ISSN: 2277-128X (Volume-8, Issue-1)

[17]. Web References: https://www.tutorialspoint.com/work_life_bala nce/index.htm

\section{Cite this article as :}

Pooja Maken, Dr. Kavita Aggarwal, "Work-Life Balance: A Study of Selected Nationalized Banks in Ambala District (Haryana)", International Journal of Scientific Research in Science and Technology (IJSRST), Online ISSN : 2395-602X, Print ISSN : 23956011, Volume 8 Issue 2, pp. 203-213, March-April 2021. Available at

doi : https://doi.org/10.32628/IJSRST218215

Journal URL : https://ijsrst.com/IJSRST218215 